\title{
Increased production of human fibroblast growth factor 17 in Escherichia coli and proliferative activity in NIH3T3 cells
}

\author{
MEIYU WU ${ }^{1,2^{*}}$, NA SONG $^{3 *}$, JILIANG CHENG $^{2}$, YANG ZHAO $^{2}$, NAZI CHEN ${ }^{2}$, \\ JISHENG MA ${ }^{2}$, XIAOKUN LI ${ }^{2}$, CHAO JIANG ${ }^{2}$ and HAIJUN WANG ${ }^{1}$ \\ ${ }^{1}$ Department of Pathology, School of Basic Medical Sciences, Xinxiang Medical University, \\ Xinxiang, Henan 453003; ${ }^{2}$ Department of Biopharmaceuticals, School of Pharmaceutical Sciences, \\ Wenzhou Medical University, Wenzhou, Zhejiang 325035; ${ }^{3}$ Department of Molecular Biology and Biochemistry, \\ School of Basic Medical Sciences, Xinxiang Medical University, Xinxiang, Henan 453003, P.R. China
}

Received April 14,2016; Accepted March 17, 2017

DOI: $10.3892 / \mathrm{mmr} .2017 .6575$

\begin{abstract}
Fibroblast growth factor 17 (FGF17) is a novel member of the FGFs family, which is essential for cell development, tissue repair, tumor growth and invasion. The aim of the current study was to obtain a high expression level of recombinant human FGF17 (rhFGF17), including soluble proteins and inclusion bodies. An optimized rhFGF17 cDNA sequence was cloned into a pET3a vector, then the pET3a-hFGF17 vector was transformed into BL21(DE3)pLysS Escherichia coli cells. Expression was induced by optimizing the conditions using isopropyl $\beta$-D-1-thiogalactopyranoside (IPTG) and it was confirmed that a 24-h exposure to $0.8 \mathrm{mM}$ IPTG at $16^{\circ} \mathrm{C}$ provided the optimal condition for soluble hFGF17. Furthermore, for the inclusion bodies, the optimal condition was a $4-\mathrm{h}$ exposure to $0.4 \mathrm{mM}$ IPTG at $37^{\circ} \mathrm{C}$. Two forms of rhFGF17 protein were purified by heparin affinity and SP Sepharose Fast Flow chromatography. MTT assays demonstrated that the purified rhFGF17 exerted an important effect on the proliferative activity of NIH3T3 cells, although there was no significant difference when compared with standard rhFGF17. Thus, an optimal and economic expression system was created in the present study for rhFGF17 in E. coli. This expression strategy enables the preparation of sufficient
\end{abstract}

Correspondence to: Dr Haijun Wang, Department of Pathology, School of Basic Medical Sciences, Xinxiang Medical University, 601 Jinsui Road, Hongqi, Xinxiang, Henan 453003, P.R. China E-mail:wnavy200299@163.com

Dr Chao Jiang, Department of Biopharmaceuticals, School of Pharmaceutical Sciences, Wenzhou Medical University, 208 Zhongxing North Road, Chashan College Park, Wenzhou, Zhejiang 325035, P.R. China

E-mail: chaojiang2015@126.com

${ }^{*}$ Contributed equally

Key words: rhFGF17, purification, soluble protein, inclusion body, proliferation activity and highly bioactive rhFGF17 for further investigation of underlying mechanisms.

\section{Introduction}

The human fibroblast growth factors (FGFs) protein family consists of 22 members, which share a high affinity for heparin, as well as high-sequence homology within a central core domain of 120 amino acids (1). FGFs are essential in biological functions, such as angiogenesis, mitogenesis, cell differentiation and wound repair. FGF17 is a member of the heparin binding growth factor family (2), which is structurally the most homologous to FGF8 and FGF18. FGF8, FGF17 and FGF18 are highly conserved between human and mice, sharing 93\% identity $(2,3)$. Mouse FGF17 has three isoforms, while human FGF17 has just two: FGF17a and FGF17b, the latter of which has been selected as the canonical sequence (4). FGF17 is preferentially expressed in the embryonic brain and is highly associated with the nervous system (5).

Numerous studies have indicated that FGF17 may serve as a therapeutic agent to potentially treat certain types of disease. There is an increasing demand in the market to produce the FGF17 protein, and the large-scale production of bioactive human FGF17 is a challenging rate-limiting step. Given these factors, the development of a process that may enable significant preparation of sufficient, highly bioactive recombinant human (rh)FGF17 is considered to be a high priority for further investigations of the underlying mechanisms and clinical pathology. With the development of biotechnology, various expression systems are currently being used for expressing recombinant proteins for industrial production, as well as in research for structural and biochemical studies (6). Escherichia coli, with a short growth cycle, low cost, high stability and high transformation efficiency, is suitable for large-scale manufacture (7). In addition, E. coli are the most frequently used expression system for high-scale production of recombinant proteins (8-10).

As human (h)FGF17 is an important growth factor and, to the best of our knowledge, its non-tag expression in E. coli has not been reported, an rhFGF17 expression vector pET3a-rhFGF17, with a high expression level of rhFGF17 protein with soluble 
protein and inclusion bodies, was constructed in the present study. Furthermore, the high purity of rhFGF17 protein was obtained via heparin affinity and SP Sepharose Fast Flow chromatography. In addition, the biological activity of rhFGF17, which may significantly increase the proliferative activity of NIH3T3 cells was examined. This novel expression strategy markedly enhanced the yield of rhFGF17 with high biological activity, which may meet the demand for fundamental research and therapeutic applications.

\section{Materials and methods}

Reagents and bacterial strain. The PCR purification, gel extraction and plasmid miniprep kits, and DNA Marker were purchased from Takara Biotechnology Co., Ltd. (Dalian, China). Goat anti-FGF17 polyclonal antibody (cat. no. sc-16826) and mouse anti-goat IgG-HRP (cat. no. sc-2354) were purchased from Santa Cruz Biotechnology, Inc. (Dallas, TX, USA). Heparin Sepharose column, SP Sepharose Fast Flow and AKTA purifier were purchased from GE Healthcare Life Sciences (Shanghai, China). The E. coli DH5 $\alpha$ and BL21(DE3)pLysS component cells were purchased from Beijing Solarbio Science \& Technology Co., Ltd. (Beijing, China).

Construction of rhFGF17 expression vector. The coding sequence of rhFGF17 (GenBank reference, NM_001304478.1) was obtained from the pUC57-FGF17 vector, previously constructed by our lab (unpublished data), using a Veriti ${ }^{\mathrm{TM}}$ Thermal Cycler (cat. no. 4375786; Thermo Fisher Scientific, Inc., Waltham, MA, USA) with Phusion ${ }^{\circledR}$ High-Fidelity PCR Master Mix (cat. no. M0531S; New England BioLabs, Inc., Ipswich, MA, USA). Amplification conditions were as follows: Initial denaturation at $98^{\circ} \mathrm{C}$ for $30 \mathrm{sec}$, followed by 30 cycles at $98^{\circ} \mathrm{C}$ for $10 \mathrm{sec}$, at $65^{\circ} \mathrm{C}$ for $20 \mathrm{sec}$ and at $72^{\circ} \mathrm{C}$ for $20 \mathrm{sec}$, with a final extension step at $72^{\circ} \mathrm{C}$ for $10 \mathrm{~min}$. The DNA fragment rhFGF17 was subsequently cloned into pET3a vector, using the NdeI and BamHI restriction enzymes, to create the recombinant expression vector, pET3a-hFGF17, according to the manufacturer's protocol. NdeI (cat. no. R0111S) and BamHI (cat. no. R0136S) were purchased from New England BioLabs, Inc.

Production of rhFGF17. The recombinant vector pET3a-hFGF17 was transformed into BL21(DE3)PLysS component cells. Briefly, 50 ng pET3a-hFGF17 vector were added to $100 \mu 1$ thawed BL21(DE3)PLysS component cells. Cells were incubated for $30 \mathrm{~min}$ on ice, heat shocked at $42^{\circ} \mathrm{C}$ for $90 \mathrm{sec}$, and then plated on a pre-warmed LB agar plate for further culture. The transformed colonies were cultured in $5 \mathrm{ml}$ LB medium (tryptone $10 \mathrm{~g} / \mathrm{l}$, yeast extract $5 \mathrm{~g} / \mathrm{l}, \mathrm{NaCl} 5 \mathrm{~g} / \mathrm{l}$, in $\mathrm{ddH}_{2} \mathrm{O}$ ) containing $100 \mu \mathrm{g} / \mathrm{ml}$ ampicillin and $35 \mu \mathrm{g} / \mathrm{ml}$ chloramphenicol at $37^{\circ} \mathrm{C}$. When the optical density (OD) ${ }_{600}$ reached 0.6-0.8, isopropyl $\beta$-D-1-thiogalactopyranoside (IPTG) was added to a final concentration of $1 \mathrm{mM}$. The cultures were incubated at $37^{\circ} \mathrm{C}$ for $4 \mathrm{~h}$ under agitation (speed, $200 \mathrm{rpm}$ ). The colony with the greatest expression level was selected as the seed strain in subsequent experiments.

Optimizing the expression conditions for rhFGF17. The IPTG concentration for rhFGF17 expression yield was evaluated at $37^{\circ} \mathrm{C}$ and $16^{\circ} \mathrm{C}$. Detection of soluble rhFGF17 was performed as follows: The seed strain was cultured overnight with agitation at $200 \mathrm{rpm}$ in $20 \mathrm{ml} \mathrm{LB}$ medium containing $10 \mu \mathrm{g} / \mathrm{ml}$ ampicillin and $35 \mu \mathrm{g} / \mathrm{ml}$ chloramphenicol at $37^{\circ} \mathrm{C}$. Subsequently, the culture $(6 \mathrm{ml})$ was transferred into two bottles, each containing $600 \mathrm{ml}$ fresh LB medium with $100 \mu \mathrm{g} / \mathrm{ml}$ ampicillin and $35 \mu \mathrm{g} / \mathrm{ml}$ chloramphenicol for further growth. When $\mathrm{OD}_{600}$ reached 0.6-0.8, the IPTG was added to final concentrations of 0.4 and $1 \mathrm{mM}$, and cultured for $4 \mathrm{~h}$ at $37^{\circ} \mathrm{C}$ (speed, $200 \mathrm{rpm}$ ) and $24 \mathrm{~h}$ at $16^{\circ} \mathrm{C}$ (speed, $180 \mathrm{rpm}$ ). Cells were collected by centrifugation at $15,000 \mathrm{x}$ g for $20 \mathrm{~min}$ at $4^{\circ} \mathrm{C}$. The cell pellets were resuspended in improved lysis buffer $[20 \mathrm{mM}$ Tris-HCl, $200 \mathrm{mM}$ Nacl, $1 \%$ Triton X-100, $0.2 \%$ deoxysodium cholate, $1 \mathrm{mM}$ EDTA, 5\% glycerol, $0.2 \mathrm{M}$ sucrose and $1 \mathrm{mM}$ phenylmethylsulfonyl fluoride (PMSF; pH 7.5)]. Cells were lysed by sonication for $10 \mathrm{~min}$ in an ice bath. Following centrifugation at $15,000 \mathrm{x}$ g for $20 \mathrm{~min}$ at $4^{\circ} \mathrm{C}$, the sediment and the supernatant were separated by $12 \%$ SDS-PAGE and the protein expression levels of rhFGF21 were determined, using western blot analysis.

Purification of soluble rhFGF17. The bacteria cells were harvested and lysed in lysis buffer ( $\mathrm{pH} 7.5$ ) containing $50 \mathrm{mM}$ Tris-HCl, 2 mM EDTA, $300 \mathrm{mM} \mathrm{NaCl}, 1 \%$ Triton X-100, $0.2 \%$ deoxysodium cholate, $5-10 \%$ glycerol, $0.01 \mathrm{M}$ sucrose and $1 \mathrm{mM}$ PMSF. Supernatants were collected for subsequent purification. The following steps were all performed at $4^{\circ} \mathrm{C}$ : First, the heparin-sepharose column was equilibrated with five bed volumes of binding buffer $(20 \mathrm{mM}$ Tris- $\mathrm{HCl}$ buffer, $25 \mathrm{mM} \mathrm{NaCl}$ and $1 \mathrm{mM}$ EDTA; $\mathrm{pH} 7.5$ ) at a rate of $1 \mathrm{ml} / \mathrm{min}$. Subsequently, the supernatant was applied to the column. Following binding, the column was washed with binding buffer with gradients of $0.4,0.6,0.8$ and $1.0 \mathrm{M} \mathrm{NaCl}$. Further purification was performed using an SP Sepharose Fast Flow, where the methodology was the same as the heparin-sepharose purification. Finally, fractions were collected from the column according to the ultraviolet absorption peaks and conductivity curve. Then the elution fractions were determined using $12 \%$ SDS-PAGE.

Isolation and refolding of rhFGF17 inclusion bodies. Following fermentation, bacteria were harvested by centrifugation at $10,000 \times \mathrm{g}$ at $4^{\circ} \mathrm{C}$ for $15 \mathrm{~min}$, and wet bacteria $(1 \mathrm{~g})$ was resuspended in $20 \mathrm{ml}$ lysis buffer. The inclusion bodies were collected following centrifugation at $10,000 \mathrm{x} \mathrm{g}$ at $4^{\circ} \mathrm{C}$ for $15 \mathrm{~min}$ and resuspended in wash buffer $(20 \mathrm{mM}$ Tris-HCl, $200 \mathrm{mM} \mathrm{NaCl}, 1 \%$ Triton X-100 and 1 mM EDTA; pH10) by centrifugation at $10,000 \mathrm{xg}$ at $4^{\circ} \mathrm{C}$ for 15 min after ultrasonication in an ice bath. Subsequently, inclusion bodies $(1 \mathrm{~g})$ were resuspended in $20 \mathrm{ml}$ denaturing buffer $(8 \mathrm{M}$ urea, $20 \mathrm{mM}$ Tris, $150 \mathrm{mM} \mathrm{Nacl}, 3 \mathrm{mM}$ EDTA, $5 \mathrm{mM}$ DTT and $0.5 \mathrm{M}$ arginine; $\mathrm{pH}$ 7.5). The protein was then refolded by a combination of dialysis and slow dilution. First, the denaturing buffer was dialyzed in dialysis buffer $(20 \mathrm{mM}$ Tris, $50 \mathrm{mM}$ $\mathrm{NaCl}, 15 \%$ glycerol, $0.5 \mathrm{M}$ arginine and $4 \mathrm{M}$ urea; $\mathrm{pH} 7.5$ ) until the urea concentration reached $4 \mathrm{M}$; subsequently, the buffer in the dialysis bag were collected by centrifugation at $10,000 \mathrm{x}$ g at $4^{\circ} \mathrm{C}$ for $15 \mathrm{~min}$ and then slowly diluted into appropriate volumes of renaturing buffer $(20 \mathrm{mM}$ Tris- $\mathrm{HCl}$, $50 \mathrm{mM} \mathrm{NaCl}, 30 \%$ glycerol and $0.5 \mathrm{M}$ arginine; $\mathrm{pH} 7.5$ ). 
Following centrifugation at $15,000 \times \mathrm{g}$ at $4^{\circ} \mathrm{C}$ for $20 \mathrm{~min}$, the supernatant was retained and prepared for inclusion in the heparin-sepharose column. Refolding of the protein was performed at $4^{\circ} \mathrm{C}$.

Purification of rhFGF17 inclusion bodies. According to the heparin affinity of rhFGF17, a heparin-sepharose column was selected for the purification. Purification procedures were the same as soluble rhFGF17. Refolding rhFGF17 protein was loaded onto the column that was equilibrated with wash buffer (the same as the soluble fraction) at a speed of $1 \mathrm{ml} / \mathrm{min}$. The flow-through was collected. The protein was subsequently eluted using $0.4-1.0 \mathrm{M} \mathrm{NaCl}$ gradient in wash buffer at a speed of $1 \mathrm{ml} / \mathrm{min}$. The elution fractions were collected and determined by Coomassie blue staining of $12 \%$ SDS-PAGE.

Western blot analysis. Protein concentration was determined using the Lowry protein assay. Purified rhFGF17 proteins (50 ng) were separated by $12 \%$ SDS-PAGE and transferred onto polyvinylidene difluoride membranes. The membranes were blocked with $5 \%$ non-fat milk for $20 \mathrm{~min}$ at room temperature, and then incubated with primary antibodies at $4^{\circ} \mathrm{C}$ overnight, followed by incubation with the secondary antibody at room temperature for $30 \mathrm{~min}$. Protein bands were visualized by enhanced chemiluminescence using the ChemiDoc $^{\mathrm{TM}}$ MP Imaging System (Bio-Rad Laboratories, Inc., Hercules, CA, USA). Goat anti-FGF17 polyclonal antibody served as the primary antibody (dilution, 1:1,000) and mouse anti-goat IgG-HRP was used as the secondary antibody (dilution, 1:8,000). The molecular sizes of the obtained protein were verified by comparison with the migration of pre-stained protein markers (cat. no. 26616; Thermo Fisher Scientific, Inc.).

Mitogenic activity of rhFGF17 assay. NIH3T3 cells $\left(2 \times 10^{3}\right.$ cells/well) were cultured in Dulbecco's modified Eagle's medium (DMEM) containing $10 \%$ fetal bovine serum (Thermo Fisher Scientific, Inc.) in a 96 -well plate at $37^{\circ} \mathrm{C}$ for $24 \mathrm{~h}$. The medium was then replaced with DMEM supplemented with $1 \%$ FBS and cells were starved overnight. The cells were treated with different concentrations of rhFGF17 or commercial rhFGF17 (R\&D Systems China Co., Ltd., Shanghai, China) for $48 \mathrm{~h}$ and the number of viable cells was determined by adding $25 \mu 1 \mathrm{MTT}(5 \mathrm{mg} / \mathrm{ml})$ per well for $4 \mathrm{~h}$. Finally, the medium was discarded and $150 \mu \mathrm{l}$ dimethyl sulfoxide was added to each well to dissolve the crystals by agitation at room temperature for $10 \mathrm{~min}$; the absorbance was immediately measured at a wavelength of $600 \mathrm{~nm}$ using the GENESYS ${ }^{\mathrm{TM}}$ 10S UV-Vis Spectrophotometer (Thermo Fisher Scientific, Inc.).

\section{Results}

Construction of the rhFGF17 expression vector. To produce the rhFGF17 protein, an expression vector containing the optimized hFGF17 gene was constructed. The hFGF17 fragment was obtained (Fig. 1A), then digested with NdeI and BamHI and cloned into the pET3a vector to create the pET3a-rhFGF17 recombinant plasmids, which were then confirmed by restriction enzymatic analysis (Fig. 1B and C) and automated DNA sequencing.

Expression of rhFGF17 in BL21(DE3)pLysS. The recombinant plasmid was transformed into BL21(DE3)pLysS. The SDS-PAGE demonstrated that rhFGF17 was induced by $1 \mathrm{mM}$ IPTG and the apparent molecular band was $23 \mathrm{kDa}$, corresponding to the predicted molecular weight $(22.6 \mathrm{kDa}$; Fig. 2A). The greatest expression level of rhFGF17 was $30 \%$ of total protein.

Optimizing the expression of soluble rhFGF17. To establish the optimal culture conditions, the following concentrations of IPTG were evaluated: $0.2,0.4,0.8$ and $1.0 \mathrm{mM}$ at $37^{\circ} \mathrm{C}$ or $16^{\circ} \mathrm{C}$, under agitation at $180 \mathrm{rpm}$. When rhFGF17 was induced by $0.4 \mathrm{mM}$ IPTG at $37^{\circ} \mathrm{C}$ or $0.8 \mathrm{mM}$ IPTG at $16^{\circ} \mathrm{C}$, the rhFGF17 yield reached the highest level with ratios of $\sim 30$ and $20 \%$ of the total protein, respectively according to the SDS-PAGE results (Fig. 2B). Following fermentation in a 2-liter flask under the above-mentioned optimized conditions, the yield of bacteria was $\sim 9 \mathrm{~g} / 1$ at $37^{\circ} \mathrm{C}$ and $6 \mathrm{~g} / 1$ at $16^{\circ} \mathrm{C}$. Soluble detection was performed by lysis. SDS-PAGE analysis of the lysate supernatant and sediment indicated that the recombinant protein was marginally soluble at $16^{\circ} \mathrm{C}$, but inclusion bodies appeared to be formed at $37^{\circ} \mathrm{C}$ (Fig. 2C).

Purification of soluble rhFGF17. The soluble product was purified with improved lysis buffer and more soluble proteins were obtained with almost no sediment (Fig. 3A). Heparin-affinity column chromatography combined with SP-Sepharose column chromatography was used for purification of the soluble fraction of proteins. rhFGF17 was eluted with $1.0 \mathrm{M} \mathrm{NaCl}$ in elution buffer from the two columns (Fig. 3B and C), and the yield was $1 \mathrm{mg} / \mathrm{g}$ ( $1 \mathrm{mg}$ rhFGF17 from $1 \mathrm{~g}$ bacteria cells).

Purification and identification of rhFGF17 inclusion bodies. rhFGF17 inclusion bodies were predominantly produced from the culture condition of $37^{\circ} \mathrm{C}$ for $4 \mathrm{~h}$. rhFGF17 was denatured by urea and refolded in the dialysis buffer by dialysis and then renaturing buffer by dilution at $\mathrm{pH} 7.5$ (Fig. 4A). As indicated in Fig. 4A denaturing buffer dissolved the majority of the rhFGF17. The concentration of total protein in the denaturing buffer was $\sim 41 \mathrm{mg} / \mathrm{ml}$ and in the renaturing buffer prior to applying it to the heparin-sepharose column, total protein was decreased to $\sim 2 \mathrm{mg} / \mathrm{ml}$. As demonstrated in Fig. $4 \mathrm{~B}$ the fractions containing rhFGF17 were finally eluted by heparin affinity chromatography using $20 \mathrm{mM}$ Tris- $\mathrm{HCl}$ containing $1.0 \mathrm{M} \mathrm{NaCl}$. The purified rhFGF17 protein yield reached $8 \mathrm{mg} / \mathrm{g}$ (8 mg rhFGF17 from $1 \mathrm{~g}$ bacteria cells).

The purified soluble rhFGF17 and rhFGF17 inclusion bodies were homogenous and their purity was $>95 \%$. Western blot analysis demonstrated that the purified rhFGF17 had good immunoreactivity with the anti-human FGF17 antibody (Fig. 4C).

Mitogenic activity of rhFGF17. To assess the biological activity of purified rhFGF17, the proliferative effect of rhFGF17 was determined using a standard MTT assay on NIH3T3 cells and compared with commercial rhFGF17 (the positive control). As shown in Fig. 5, the two purified soluble forms and inclusion 

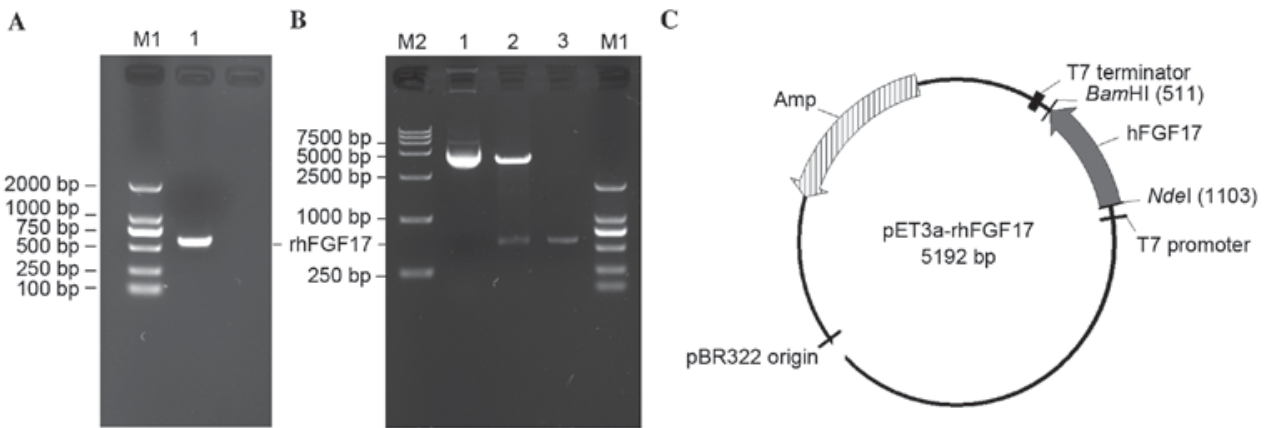

Figure 1. Construction of the pET3a-rhFGF17 expression vector. (A) rhFGF17 fragment obtained from pUC57-FGF17 by polymerase chain reaction amplification. Lane 1, FGF17 (597 bp); lane M1, DNA marker 1. (B) Identification of recombinant plasmid by enzyme digestion (NdeI and BamHI); Lane 1, pET3a-rhFGF17; lane 2, restriction products of recombinant plasmid pET3a-rhFGF17; lane 3, rhFGF17 fragment control; lane M1, DNA marker 1; lane M2 DNA marker 2. (C) Structure of the pET3a-rhFGF17 vector. rhFGF17, recombinant human fibroblast growth factor 17.

$\mathbf{A}$

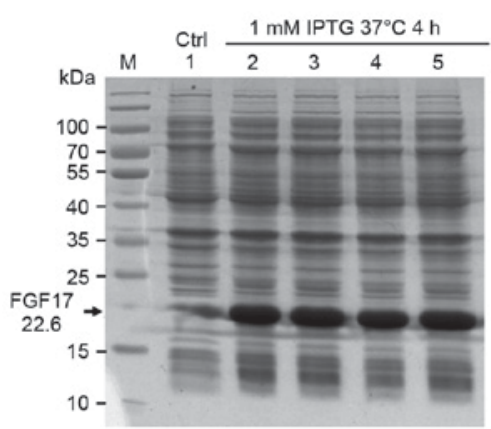

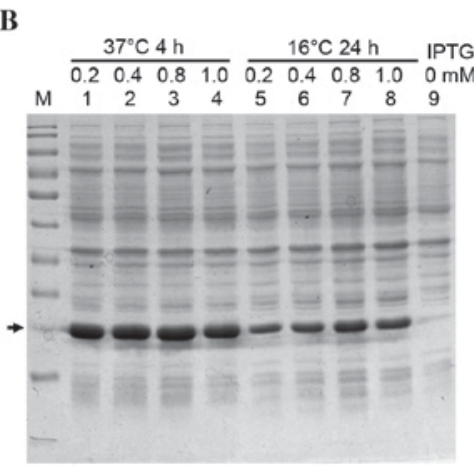

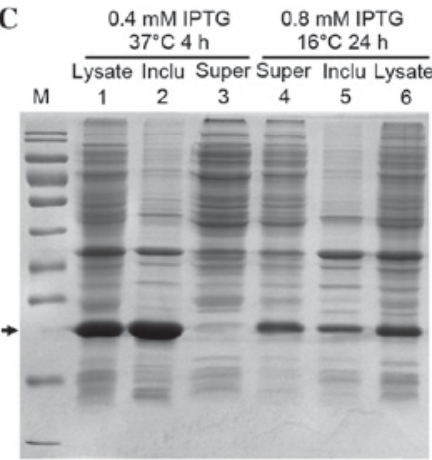

Figure 2. Optimizing the expression conditions of rhFGF17. (A) SDS-PAGE analysis of rhFGF17 expression in BL21(DE3)PLysS induced by 1 mM IPTG for $4 \mathrm{~h}$ at $37^{\circ} \mathrm{C}$. Lane 1, served as a control and was not induced with IPTG; lanes 2-5, induced with IPTG; (B) Optimizing the expression conditions of rhFGF17. Lanes 1-4 and 5-8: $0.2,0.4,0.8,1.0 \mathrm{mM}$ IPTG induced at $37^{\circ} \mathrm{C}$ for $4 \mathrm{~h}$ and $16^{\circ} \mathrm{C}$ for $24 \mathrm{~h}$, respectively. (C) Distribution of rhFGF17. Lanes $1-3,37^{\circ} \mathrm{C}$ culture (lane 1, induced BL21(DE3)PLysS/pET3a-rhFGF17; lane 2, inclusion bodies of bacteria following ultrasonication; and lane 3, supernatant). Lanes 4-6, $6^{\circ} \mathrm{C}$ culture (lane 4, supernatant of bacteria following ultrasonication; lane 5, inclusion bodies; and lane 6, induced BL21(DE3)PLysS/pET3a-rhFGF17. rhFGF17, recombinant human fibroblast growth factor 17; IPTG, isopropyl $\beta$-D-1-thiogalactopyranoside; Ctrl, control.

A

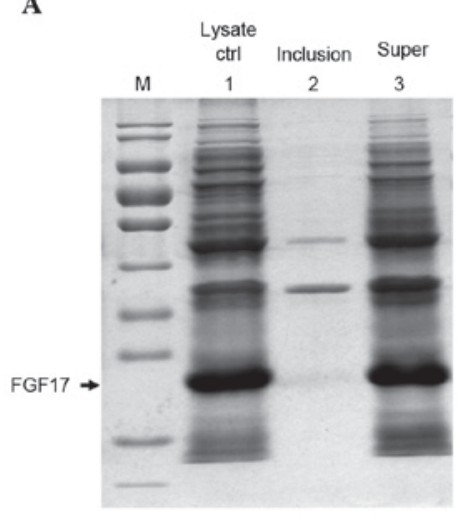

- B

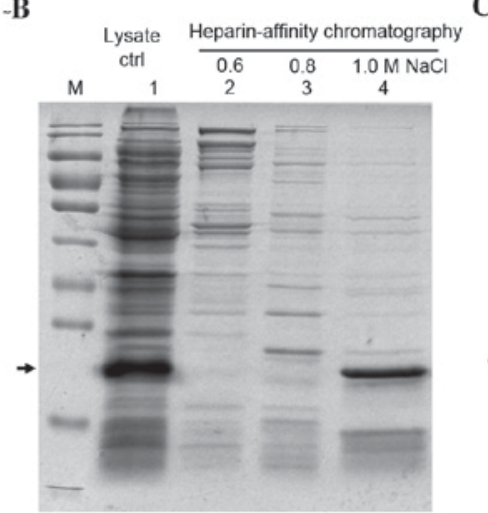

C

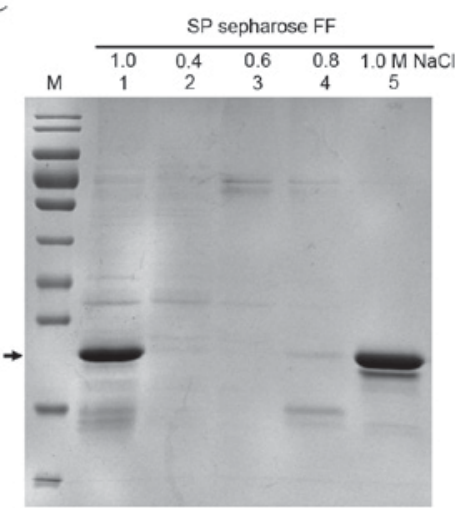

Figure 3. SDS-PAGE analysis of the purification of soluble rhFGF17 using improved lysis buffer. (A) Lane 1, lysate control; lane 2, inclusion bodies of bacteria following ultrasonication; lane 3, supernatant. (B) Purification of soluble rhFGF17 with heparin-affinity chromatography (lanes 2-4). Lane 1, supernatant of bacteria after ultrasonication; lane 2-4 eluted with 0.6, 0.8, $1.0 \mathrm{M} \mathrm{NaCl}$ from heparin-affinity chromatography, (C) Lanes 1-5, SP Sepharose Fast Flow of rhFGF17 eluted with different $\mathrm{NaCl}$ concentrations. Lane1 and 5, 1.0 M NaCl; lanes 2-4, 0.4, 0.6 and $0.8 \mathrm{M} \mathrm{NaCl}$. The arrow indicates the rhFGF17 band site. rhFGF17, recombinant human fibroblast growth factor 17; Ctrl, control; FF, fast flow.

bodies of rhFGF17 demonstrate similar mitogenic activity in NIH3T3 cells, which is consistent with the findings of a previous study (11). Additionally, compared with the commercial rhFGF17, the rhFGF17 protein formed during the present study exhibited improved biological activity. Furthermore,
rhFGF17 was found to have a dose-dependent effect on the viability of NIH3T3 cells, whereas the negative control did not. Finally, the results demonstrated that the soluble and inclusion body forms of rhFGF17 had a marked biological effect on NIH3T3 cells. 


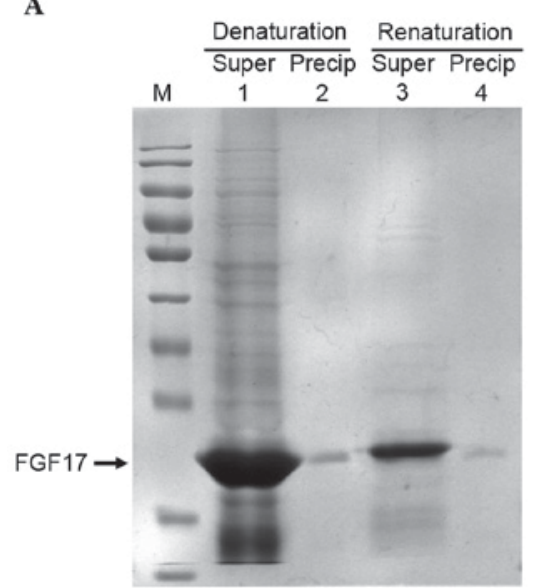

B

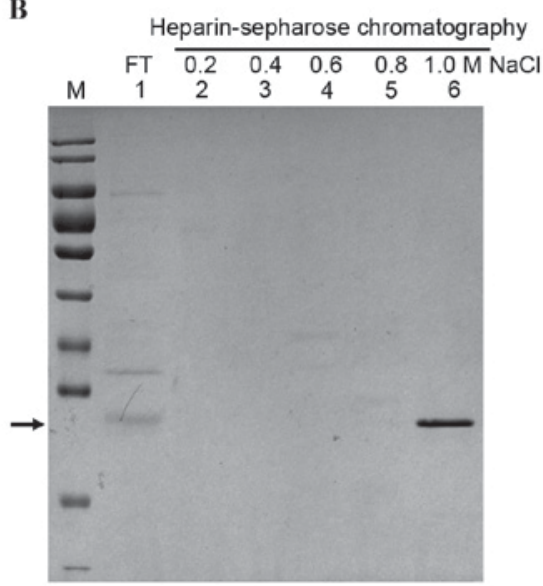

C

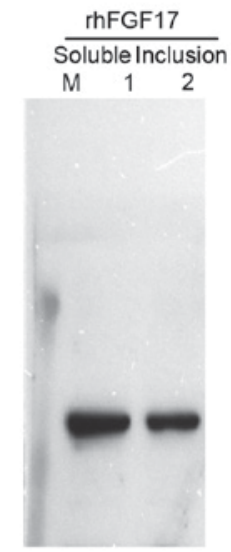

Figure 4. SDS-PAGE analysis of the purification of rhFGF17 inclusion bodies. (A) Lanes 1 and 3, Supernatant rhFGF17 and precipitation rhFGF17 in denaturation and renaturation buffer; lanes 2 and 4, Precipitation rhFGF17 in denaturation and renaturation buffer. (B) Heparin-sepharose chromatography. Lane 1, FT; lanes 2-6, eluted rhFGF17 with $20 \mathrm{mM}$ Tris-HCl containing 0.2, 0.4, 0.6, 0.8 and 1.0 M NaCl, respectively. (C) Western blot analysis of rhFGF17. Lane 1, purified soluble rhFGF17; lane 2, purified rhFGF17 inclusion bodies. rhFGF17, recombinant human fibroblast growth factor 17; FT, flow through.

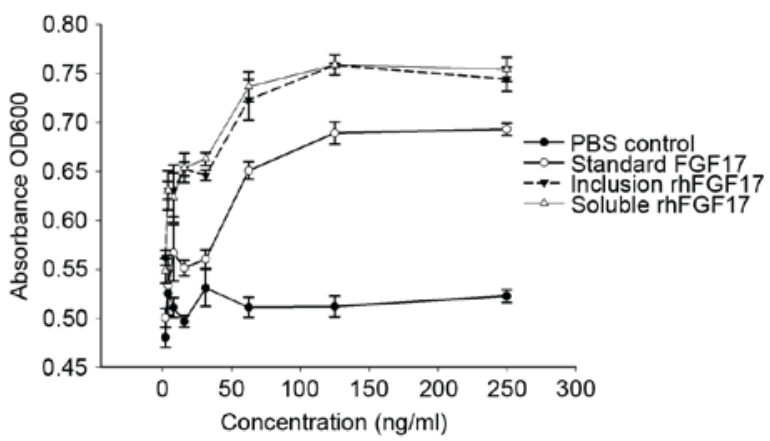

Figure 5. Mitogenic activity of rhFGF17 on NIH3T3 cells. Data are expressed as the mean \pm standard deviation. rhFGF17, recombinant human fibroblast growth factor 17; OD, optical density; PBS, phosphate-buffered saline.

\section{Discussion}

As a novel member of the FGF family, numerous pharmacological studies have demonstrated that FGF17 is a key factor in neuropsychiatric diseases due to its important roles in the patterning of the cerebellum and cortex (12). As a potential carcinogen, FGF17 is predominantly associated with prostate cancer (13) and hematopoietic tumors (14). Therefore, it is necessary to investigate FGF17 and develop strategies for abundant production of FGF17 with high bioactivity. As reported previously, the recombinant form of FGF17 protein was produced using insect cells; however, compared with prokaryotic expression systems, eukaryotic systems are considered unsuitable for large-scale purification (15). To date, there are few reports regarding the expression of hFGF17, particularly in E. coli expression systems. The low level of soluble production and difficulty purifying inclusion bodies, particularly denaturing and refolding, has restricted further research and application. There are certain methods used to overcome these limitations, including fusion systems to enhance target protein expression, such as Halo-tag fusion (16). However, the method for obtaining target protein requires that the fused tag must be removed, which involves an expensive cleavage restriction enzyme and may impact the bioactivity of the target protein.

Low temperatures increase the expression levels of soluble proteins and reduce the aggregation of recombinant proteins, thus reducing the formation of inclusion bodies (17). In addition, low agitation speeds will reduce the speed of bacteria proliferation, but increase the amount of soluble proteins. Therefore, in the current study, the culture conditions at $37^{\circ} \mathrm{C}$ and $200 \mathrm{rpm}$, and $16^{\circ} \mathrm{C}$ and $180 \mathrm{rpm}$ would yield high levels of inclusion bodies and soluble proteins, respectively. To further improve the production levels of the target protein, the expression conditions were optimized according to the IPTG concentration, thus the expression level of inclusion bodies and soluble protein reached $>30$ and $>20 \%$ of total protein, respectively with $0.4 \mathrm{mM}$ IPTG for $4 \mathrm{~h}$ at $37^{\circ} \mathrm{C}$ and $1 \mathrm{mM}$ IPTG for $24 \mathrm{~h}$ at $16^{\circ} \mathrm{C}$. Meanwhile, the lysis buffer was improved by the addition of more Tris, glycerol and sucrose; thus, a soluble protein was obtained with almost no sediment (Fig. 3A). Taken together, the conditions were improved and high production levels of target protein were achieved for purification.

Based on an isoelectric point of 10.43 and the heparin binding ability for rhFGF17, the non-fusion rhFGF17 protein was efficiently separated by heparin-sepharose chromatography and SP Sepharose Fast Flow $(18,19)$. The purified rhFGF17 proteins were biologically active in vitro and exerted a dose-dependent effect on the proliferation of NIH3T3 cells; inclusion-bodies were demonstrated to have a biological activity similar to the soluble proteins. Thus, the soluble proteins and inclusion bodies obtained using the culture conditions at $37^{\circ} \mathrm{C}$ and $200 \mathrm{rpm}$, and $16^{\circ} \mathrm{C}$ and $180 \mathrm{rpm}$, respectively, are efficiently produced and are characterized by high levels of bioactivity. Furthermore, FGF17 has previously been reported to be involved in Kallmann syndrome (20) and causes tamoxifen resistance in vitro (21). Therefore, whether there is a direct association between FGF17 and breast cancer requires further investigation.

In conclusion, soluble and inclusion bodies of rhFGF17 were successfully expressed in E. coli. The current study indicates that the non-tagged expression of either soluble proteins 
or inclusion bodies of rhFGF17 is simple, viable and highly effective, making it convenient for high-efficiency expression and purification of proteins, whilst preserving the high biological activity levels.

\section{Acknowledgements}

The present study was supported by Zhejiang Extremely Key Subject of Pharmacology and Biochemical Pharmaceutics and the National '863' High Technology Research and Development Program (grant No. 2011AA02A113) and Initiation Founding of Xingxiang Medical University (grant nos. XYBSKYZZ201512 and 201513).

\section{References}

1. Ornitz DM and Itoh N: The Fibroblast Growth Factor signaling pathway. Wiley Interdiscip Rev Dev Biol 4: 215-266, 2015.

2. Hoshikawa M, Ohbayashi N, Yonamine A, Konishi M, Ozaki K, Fukui S and Itoh N: Structure and expression of a novel fibroblast growth factor, FGF17, preferentially expressed in the embryonic brain. Biochem Biophys Res Commun 244: 187-191, 1998.

3. Ohbayashi N, Hoshikawa M, Kimura S, Yamasaki M, Fukui S and Itoh N: Structure and expression of the mRNA encoding a novel fibroblast growth factor, FGF-18. J Biol Chem 273: 18161-18164, 1998.

4. Xu J, Lawshe A, MacArthur CA and Ornitz DM: Genomic structure, mapping, activity and expression of fibroblast growth factor 17. Mech Dev 83: 165-178, 1999.

5. O'Leary DD, Chou SJ and Sahara S: Area patterning of the mammalian cortex. Neuron 56: 252-269, 2007.

6. Dong X, Tang B, Li J, Xu Q, Fang S and Hua Z: Expression and purification of intact and functional soybean (Glycine max) seed ferritin complex in Escherichia coli. J Micro Biotech 18: 299-307, 2008

7. Jana S and Deb JK: Strategies for efficient production of heterologous proteins in Escherichia coli. Appl Microbiol Biotechnol 67: 289-298, 2005

8. Derynck R, Roberts AB, Winkler ME, Chen EY and Goeddel DV: Human transforming growth factor-alpha: Precursor structure and expression in E. coli. Cell 38: 287-297, 1984.

9. Verdon J, Girardin N, Marchand A, Héchard Y and Berjeaud JM: Purification and antibacterial activity of recombinant warnericin RK expressed in Escherichia coli. Appl Microbiol Biotechnol 97: 5401-5412, 2012
10. Ajikumar PK, Xiao WH, Tyo KE, Wang Y, Simeon F, Leonard E, Mucha O, Phon TH and Pfeifer B: Isoprenoid pathway optimization for Taxol precursor overproduction in Escherichia coli. Science 330: 70-74, 2010

11. Song L, Huang Z, Chen Y, Li H, Jiang C and Li X: High-efficiency production of bioactive recombinant human fibroblast growth factor 18 in Escherichia coli and its effects on hair follicle growth. Appl Microbiol Biotechnol 98: 695-704, 2014.

12. Tabarés-Seisdedos R and Rubenstein JL: Chromosome 8p as a potential hub for developmental neuropsychiatric disorders: Implications for schizophrenia, autism and cancer. Mol Psychiatry 14: 563-589, 2009.

13. Heer R, Douglas D, Mathers ME, Robson CN and Leung HY: Fibroblast growth factor 17 is over-expressed in human prostate cancer. J Pathol 204: 578-586, 2004.

14. Nezu M, Tomonaga T, Sakai C, Ishii A, Itoga S, Nishimura M, Matsuo Y, Tagawa M and Nomura F: Expression of the fetal-oncogenic fibroblast growth factor-8/17/18 subfamily in human hematopoietic tumors. Biochem Biophys Res Commun 335: 843-849, 2005 .

15. Hoshikawa M, Ohbayashi N, Yonamine A, Konishi M, Ozaki K, Fukui S and Itoh N: Structure and expression of a novel fibroblast grow th factor, FGF-17, preferentially expressed in the embryonic brain. Biochem Biophys Res Commun 244: 187-191, 1998.

16. Sun C, Li Y, Taylor SE, Mao X, Wilkinson MC and Fernig DG: Halo Tag is an effective expression and solubilisation fusion partner for a range of fibroblast growth factors. Peer J 3: e1060, 2015.

17. de Groot NS and Ventura S: Effect of temperature on protein quality in bacterial inclusion bodies. FEBS Lett 580: 6471-6476, 2006.

18. Berman B, Ostrovsky O, Shlissel M, Lang T, Regan D, Vlodavsky I, Ishai-Michaeli R and Ron D: Similarities and differences between the effects of heparin and glypican-1 on the bioactivity of acidic fibroblast growth factor and the keratinocyte growth factor. J Biol Chem 274: 36132-36138, 1999.

19. Lee YF, Schmidt M, Graalfs H, Hafner M and Frech C: Modeling of dual gradient elution in ion exchange and mixed-mode chromatography. J Chromatogr A 1417: 64-72, 2015.

20. Miraoui H, Dwyer AA, Sykiotis GP, Plummer L, Chung W, Feng B, Beenken A, Clarke J, Pers TH, Dworzynski P, et al: Mutations in FGF17, IL17RD, DUSP6, SPRY4, and FLRT3 are identified in individuals with congenital hypogonadotropic hypogonadism. Am J Hum Genet 92: 725-743, 2013.

21. Meijer D, Sieuwerts AM, Look MP, van Agthoven T, Foekens JA and Dorssers LC: Fibroblast growth factor receptor 4 predicts failure on tamoxifen therapy in patients with recurrent breast cancer. Endocr Relat Cancer 15: 101-111, 2008. 